\title{
BMJ Open Hearing loss in workers exposed to epoxy adhesives and noise: a cross-sectional study
}

\author{
Hsiao-Yu Yang, ${ }^{1,2}$ Ruei-Hao Shie, ${ }^{3}$ Pau-Chung Chen ${ }^{1,2,4}$
}

To cite: Yang $\mathrm{H}-\mathrm{Y}$, Shie $\mathrm{R}-\mathrm{H}$, Chen P-C. Hearing loss in workers exposed to epoxy adhesives and noise: a cross-sectional study. BMJ Open 2016;6:e010533. doi:10.1136/bmjopen-2015010533

- Prepublication history and additional material is available. To view please visit the journal (http://dx.doi.org/ 10.1136/bmjopen-2015010533).

Received 12 November 2015 Revised 22 December 2015 Accepted 25 January 2016

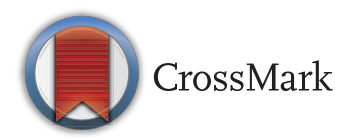

For numbered affiliations see end of article.

Correspondence to Dr Hsiao-Yu Yang; hyang@ntu.edu.tw

\section{ABSTRACT}

Objectives: Epoxy adhesives contain organic solvents and are widely used in industry. The hazardous effects of epoxy adhesives remain unclear. The objective of this study was to investigate the risk of hearing loss among workers exposed to epoxy adhesives and noise. Design: Cross-sectional study.

Methods: For this cross-sectional study, we recruited 182 stone workers who were exposed to both epoxy adhesives and noise, 89 stone workers who were exposed to noise only, and 43 workers from the administrative staff who had not been exposed to adhesives or noise. We obtained demographic data, occupational history and medical history through faceto-face interviews and arranged physical examinations and pure-tone audiometric tests. We also conducted walk-through surveys in the stone industry. A total of 40 representative noise assessments were conducted in 15 workplaces. Air sampling was conducted at 40 workplaces, and volatile organic compounds were analysed using the Environmental Protection Agency (EPA) T0-15 method.

Results: The mean sound pressure level was 87.7 dBA (SD 9.9). The prevalence of noise-induced hearing loss was considerably increased in the stone workers exposed to epoxy adhesives (42\%) compared with the stone workers who were not exposed to epoxy adhesives (21\%) and the administrative staff group (9.3\%). A multivariate logistic regression analysis revealed that exposure to epoxy adhesives significantly increased the risk of hearing loss between 2 and $6 \mathrm{kHz}$ after adjusting for age. Significant interactions between epoxy adhesives and noise and hearing impairment were observed at 3, 4 and $6 \mathrm{kHz}$.

Conclusions: Epoxy adhesives exacerbate hearing impairment in noisy environments, with the main impacts occurring in the middle and high frequencies.

\section{INTRODUCTION}

Organic solvents are heavily used in industry. Organic solvents present at workplaces typically contain a variety of chemicals because of adulteration or impurity. There is increasing evidence that exposure to organic solvents has hazardous effects on hearing. ${ }^{1-3}$

\section{Strengths and limitations of this study}

- Though epoxy resins are widely used in industry, this is the first epidemiological study to demonstrate a synergistic interaction between noise and epoxy adhesives in hearing impairment.

- This study evaluated in detail the components of organic solvents used in epoxy adhesives, enabling us to assess health effects among workers exposed to mixed solvents.

- The sampling times of volatile organic compounds were randomly selected, and the concentrations were restricted to compare with the regulated permissible exposure levels that were established on the basis of a time-weighted average exposure over a nominal $8 \mathrm{~h}$ period.

However, the effects of organic solvents on hearing are difficult to evaluate because workers are usually exposed to a mixture of solvents with widely varying compositions and concentrations. ${ }^{4-6}$ Furthermore, in industrial settings, exposure to chemicals often co-occurs with an elevated noise level, which makes it difficult to distinguish the effects of solvents from noise-induced hearing loss. ${ }^{7-9}$

Epoxy resins are one of the most important and widely used types of polymeric systems in industry. The common uses of epoxy resin systems include adhesives, paints, coatings, sealants, inks, fillers, reinforced polymer composites and varnishes. Epoxy adhesive formulations include a combination of epoxy monomers, curing agents (hardeners), diluents and a vast number of chemical ingredients. Many composite materials in epoxy systems can cause asthma ${ }^{8}$ and contact dermatitis. $^{7-9}$ Styrene, chlorobenzene and carbon disulfide are commonly used as diluents for epoxy adhesives and are more volatile than other components. ${ }^{10}$ However, the organic solvents used in epoxy resins are complex, and the hazardous effects on hearing among workers exposed to epoxy 
adhesives remain unclear. Epoxy resin is widely used in the stone industry. ${ }^{8}$ Stone workers were reported to have a high prevalence of hearing defects. ${ }^{11}$ The objective of this study was to investigate a possible synergistic effect on hearing loss in workers exposed to epoxy adhesives and noise. We hypothesised that workers exposed to both epoxy adhesives and noise would have an increased risk of hearing loss. To test this hypothesis, we measured the organic solvents used in the stone industry and assessed the interactions between exposure to epoxy adhesives and noise on hearing loss.

\section{METHODS}

\section{Study design and population}

This study was conducted on the basis of an occupational cohort of the stone-processing industry in Hualien, Taiwan. Most of the workers in the industry are self-employed or work in small scale enterprises with less than five workers. They are typically insured through the stone labourers' union in Hualien. Funded by the Taiwan Council of Labor Affairs, we conducted a basic occupational health service programme for the stone workers between 2006 and 2015. ${ }^{12}$ A cross-sectional study was conducted in the occupational cohort between 2009 and 2010. The establishment of the cohort was described in our previous study. ${ }^{13}$ In brief, all of the stone workers insured through the stone labourers' union in Hualien were eligible for the study. We mailed information regarding the study to 1902 members of the stone union. A total of 344 participants chose to participate in the study and received questionnaire survey and health examinations. We made at least three phone calls to each non-respondent to clarify their reasons for not participating. Among the non-respondents, $43 \%$ could not be contacted, $30 \%$ had conflicts with our scheduled times, $8 \%$ were receiving regular health examinations and had no desire to be examined again, $2 \%$ could not have an examination due to frailty, $1 \%$ believed that they were healthy and did not wish to receive an examination, $<1 \%$ could not receive an examination due to pregnancy, $<1 \%$ responded that the examination did not meet their needs, and $17 \%$ provided no reason. The reasons for non-participation were not related to existing hearing diseases. ${ }^{13}$

\section{Walk-through surveys}

A total of 47 walk-through surveys of stone-processing workplaces were completed in order to provide a general risk assessment of the industry between 2006 and 2009. The types of jobs, work environments, processing procedures, materials used in each procedure and final products were recorded. On the basis of the walk-though survey, there are seven types of jobs in the stone-processing industry in Hualien, including processing gemstones, crafting large decorations, making vases, making urns, crafting small decorations, making sculptures and manufacturing building materials. The occupational hazards in the stone industry of Hualien include: (1) Safety hazards: the risk of being pulled into the grinding machine, cutting, falls, eye splash injuries; (2) Physical hazards: noise, use of vibrating tools such as drillers, hand-held carving machines or pneumatic hammers; (3) Ergonomic hazards: repetitive movements and lifting heavy stones; (4) Chemical hazards: dusts, oxalic acid, epoxy resin and organic solvents. Epoxy adhesives are commonly used to fix rocks to lathes, to stick different stones together, to caulk cracks, and to coat and strengthen the surfaces of stones when they are carved, shaped, ground or polished. Stone workers use numerous types of epoxy adhesives, and the containers are not labelled. Stone workers generally call them 'AB glue' without knowing their components. The mixing and application of epoxy adhesives are usually performed using simple equipment without ventilation. Solvents could be inhaled and affect the workers' health. However, personal protective respiratory and hearing equipment are seldom used among these stone workers. The reports of the walk-though surveys were discussed in expert committees that included occupational medicine physicians, industrial hygienists, public officers of labour affairs and labour leaders. Representative workplaces for each type of job were selected for subsequent noise measurements and air sampling.

\section{Noise exposure assessment}

Between 2006 and 2009, we conducted a total of 40 representative noise assessments in 15 representative workplaces that covered all types of jobs for the study participants (table 1), including one gemstoneprocessing workplace, one that constructed large decorations, three vase-producing workplaces, two urn-producing workplaces, five that made small decorations, one that focused on sculptures, and two that manufactured building materials (see online supplementary table S1). This study used ANSI S1.25-1991 standard personal noise dose meters (TES-1355, TES Electrical Electronic Corp., Taipei, Taiwan) with the A-scale and slow response mode settings. The A-scale pressure levels of sound across the frequency spectrum $(20-200000 \mathrm{~Hz})$ are similar to the human hearing response. ${ }^{14}$ The audio dosimeter microphones were clipped to workers' collars. Doses were calculated on the basis of the actual exposure times at given sound pressure levels divided by the allowable exposure times at those levels. An equivalent sound pressure level in dBA for an $8 \mathrm{~h}$ workday was calculated on the basis of the integrated dose obtained from the entire work shift.

\section{Air sampling and analyses of volatile organic compounds}

To determine the contents of volatile organic compounds (VOCs) in the stone industry, field ambient air sampling was conducted at 40 workplaces from 20 June 2014 to 6 October 2014. Given the uncertainty regarding the contents of epoxy adhesives used in the stone industry and since the contents of the adhesives used in 
Table 1 Characteristics of study participants by types of jobs

\begin{tabular}{|c|c|c|c|c|c|c|c|}
\hline & $\begin{array}{l}\text { Processing } \\
\text { gemstones } \\
(n=51)\end{array}$ & $\begin{array}{l}\text { Making large } \\
\text { decorations } \\
(n=56)\end{array}$ & $\begin{array}{l}\text { Making } \\
\text { vases } \\
(n=77)\end{array}$ & $\begin{array}{l}\text { Making } \\
\text { urns } \\
(\mathrm{n}=44)\end{array}$ & $\begin{array}{l}\text { Making small } \\
\text { decorations } \\
(n=156)\end{array}$ & $\begin{array}{l}\text { Making } \\
\text { sculptures } \\
(n=58)\end{array}$ & $\begin{array}{l}\text { Manufacturing } \\
\text { building } \\
\text { materials } \\
(\mathrm{n}=46)\end{array}$ \\
\hline Men, \% & 57 & 50 & 48 & 43 & 38 & 53 & 54 \\
\hline $\begin{array}{l}\text { Age (years), mean } \\
\text { (SD) }\end{array}$ & $51.4(8.2)$ & $50.4(7.5)$ & $53.4(7.8)$ & $51.5(9.6)$ & $53.1(8.0)$ & $49.4(8.0)$ & $50.5(9.7)$ \\
\hline \multicolumn{8}{|c|}{ Duration of stone work (years) } \\
\hline \multicolumn{8}{|l|}{ Categorical, \% } \\
\hline$<20$ & 49 & 59 & 44 & 57 & 53 & 43 & 67 \\
\hline$\geq 20$ & 51 & 41 & 56 & 43 & 47 & 57 & 33 \\
\hline \multicolumn{8}{|c|}{ Cigarette smoking, \% } \\
\hline Never smoked $†$ & 51 & 67 & 65 & 75 & 73 & 65 & 67 \\
\hline Former smoker & 8 & 5 & 10 & 9 & 4 & 7 & 4 \\
\hline Current smoker & 41 & 27 & 25 & 16 & 23 & 26 & 28 \\
\hline \multicolumn{8}{|l|}{ Workplace, \% } \\
\hline Outdoors/canopy & 92 & 98 & 96 & 93 & 95 & 95 & 96 \\
\hline Enclosed room & 6 & 2 & 4 & 7 & 4 & 3 & 2 \\
\hline $\begin{array}{l}\text { Subjective noise } \\
\text { exposure at work, \% }\end{array}$ & 86 & 86 & 87 & 84 & 91 & 95 & 96 \\
\hline $\begin{array}{l}\text { Use of epoxy } \\
\text { adhesives at work, \% } \\
\text { Use of organic solvent }\end{array}$ & $\begin{array}{l}71 \\
\text { respirators, \% }\end{array}$ & 82 & 70 & 73 & 62 & 81 & 72 \\
\hline Never & 92 & 91 & 96 & 98 & 96 & 78 & 98 \\
\hline Occasionally & 4 & 5 & 3 & 2 & 2 & 9 & 2 \\
\hline Usually & 4 & 4 & 1 & 0 & 2 & 14 & 0 \\
\hline \multicolumn{8}{|c|}{ Use of earplugs or earmuffs at work, \% } \\
\hline Never & 88 & 82 & 87 & 86 & 85 & 59 & 85 \\
\hline Occasionally & 4 & 5 & 5 & 7 & 8 & 9 & 9 \\
\hline Usually & 8 & 13 & 8 & 7 & 8 & 33 & 7 \\
\hline $\begin{array}{l}\text { Noise in } 8 \mathrm{~h} \text { TWA } \\
(\mathrm{dBA}) \text {, mean (SD) }\end{array}$ & $80.1 \ddagger$ & $89.0(15.1)$ & $87.6(11.4)$ & $85.7(7.7)$ & $91.2(6.6)$ & $84.7(12.1)$ & $91.3(3.3)$ \\
\hline $\begin{array}{l}\text { Occupational hearing } \\
\text { loss, \% }\end{array}$ & 39 & 43 & 42 & 34 & 33 & 36 & 30 \\
\hline
\end{tabular}

different types of jobs or procedures may differ, this study used the TO-15 method to measure the air samples from the workplaces rather than traditional industrial hygiene sampling for particular organic compounds. The TO-15 method is a comprehensive method that has been adopted by the USA Environmental Protection Agency (US EPA) as a reference method for measuring mixtures of VOCs. All of the samples were obtained using the Entech Bottle-Vac canister (Entech Instruments Inc., Simi Valley, California, USA), a negative pressure device, with standardised procedures. A vacuum pressure of $-30 \mathrm{~mm} \mathrm{H}_{2} \mathrm{O}$ was reached using a Micro-QT Valve Vacuum Check Gauge before each sample was obtained. A total of $1 \mathrm{~L}$ of ambient air was introduced into the evacuated canister using the negative pressure for $30 \mathrm{~s}$. All of the canisters were immediately sent to the Green Energy \& Environmental Research Laboratories of Industrial Technology Research Institute (ITRI) for analysis. Gas samples were analysed using an Entech 7500A Robotic Headspace Autosampler attached to an Entech 7150 Air/Headspace Preconcentrator (Entech Instruments Inc., Simi Valley, California, USA) coupled to an Agilent 6890N gas chromatography (GC)/5975C mass spectrometer (MS) (Agilent Technologies, Santa Clara, California, USA). An internal standard that included bromochloromethane,

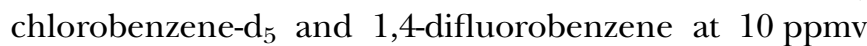
each in humidified zero air was added to each sample and calibration standard to confirm the stability of the MS and to quantify detected compounds. The internal standard was introduced into the trap at the time of collection for all of the calibration, blank and sample analyses. The volumes of the internal standard spiking mixture added to each analysis were the same from run to run. Internal standard responses and retention times were evaluated immediately after data acquisition. If the retention time for any internal standard changed by greater than $20 \mathrm{~s}$ from the mean retention time over the 
initial calibration range or if the area response for any internal standard changed by greater than $\pm 40 \%$ between the sample and the most recent valid calibration, the GC/MS system was inspected and corrected. The chromatographic data processing was performed manually by an experienced analyst using Agilent Chemstation Software (Agilent Technologies, Santa Clara, California, USA). Using the high sensitivity GC/MS analysis, hundreds of chemicals may appear in chromatography. In the analysis, mass spectrum peaks that could not be properly identified due to low library matches or a lack of confirmation by the retention time were discarded. We retained only chemicals with quality values greater than $90 \%$. The values of VOCs below the limit of detection (LOD) were replaced with the square root of $2 .{ }^{15}$ Descriptive statistics, including means, SDs, medians, and minimum and maximum values, were obtained to characterise the distributions of the concentrations of VOCs.

\section{Occupational history}

The occupational history questionnaire was designed on the basis of the reports of the walk-through surveys and had been discussed by the expert committee that includes occupational medicine physicians, industrial hygienists, public officers of labour affairs and stone worker leaders. After expert validation, the questionnaire was pretested in 10 stone workers. Any ambiguities were corrected, and a standardised set of instructions was documented. In-person interviews were conducted between September 2009 and September 2010. The participants' occupational history, including their companies, types of jobs and durations of employment, were verified against labour insurance records. The questionnaire asked about (1) the participant's occupational history of stone working. Workers were asked about the types of jobs and tasks they performed as well as the products they made. Participants were also asked about the years they began and stopped working, their actual cumulative years at specific types of job, average daily working hours, average numbers of workdays per week, subjective noise exposure at work, and use of epoxy adhesives. Additional questions focused on (2) whether they had a history of working in mining, tunnel drilling and construction, sandblasting workshops, cement factories, pulp factories or rock-crushing plants (these are the main noisy industries in Hualien) and (3) each participant's use of protective gear at work, such as masks, ventilation equipment, earplugs and earmuffs.

\section{Outcome measurements, diagnostic criteria and confounding variables}

All of the study participants received a health examination in a Hualien medical centre between 2009 and 2010. The participants completed the questionnaire survey first and then received the health examination, which was scheduled 3 months later to prevent recall bias. The health examination included a physical examination conducted by a physician and a pure tone audiogram (PTA) examination. One occupational physician performed the physical examinations and asked about the participants' medical history. The physician enquired about symptoms, signs, treatments and any hospital visits and examined the patients' hospital records to confirm the diagnoses of past diseases. Participants with other ear diseases or occupations that might be related to hearing loss other than stone work were excluded, including: (1) those with a medical history of otitis media, congenital or drug-induced hearing loss, or traumatic ear diseases and (2) participants who had worked in other noisy workplaces capable of causing occupational hearing loss, outside of those that processed stone, for more than 10 years.

Participants were prevented from noise exposure for $14 \mathrm{~h}$ before the hearing examination. The physician performed otological examinations on all of the participants to rule out any otic diseases. The PTA was obtained using test frequencies of $0.5,1,2,3,4,6$ and $8 \mathrm{kHz}$. Tests at each frequency were performed separately in each ear. Audiometric examinations were administered in a qualified audiometric test room in accordance with the national standard of Taiwan, which states that the background noise levels for audiometric tests must be less than $30 \mathrm{~dB}$ across the frequency range and that the audiometric tests must be performed by a certified hearing specialist. An occupational physician determined the presence of stone-related noise-induced hearing loss using the following criteria: (1) a confirmed occupational history of stone carving, (2) confirmation that no other work could result in hearing loss except for processing stone, (3) no history of otitis media or congenital or drug-induced hearing loss, (4) the presence of a notch at 4 or $6 \mathrm{kHz}$ and hearing threshold levels at a frequency greater than $25 \mathrm{~dB}$, and (5) symmetrical hearing loss. After excluding participants with asymmetrical hearing losses, hearing threshold levels at each frequency in the right ear were used for the analyses.

\section{Statistical analysis}

The sound levels between different types of jobs were compared using one-way analysis of variance (ANOVA) tests. Multivariate logistic regressions were used to adjust for the confounding effects of age. The age-adjusted ORs for hearing threshold levels of greater than $25 \mathrm{~dB}$ at each frequency were calculated. Study participants were stratified into three exposure groups: (1) stone workers with epoxy adhesive exposure, (2) stone workers without epoxy adhesive exposure and (3) administrative staff. The administrative staff was used as the reference group to assess the dose-response relationship for hearing losses greater than $25 \mathrm{~dB}$ at each frequency. The Cochran-Armitage test was used to test for trends. To explore the interactions between noise and epoxy adhesives on the hearing loss at each frequency, we stratified participants by epoxy adhesive exposure and 
compared the ORs for hearing losses of greater than $25 \mathrm{~dB}$. If there were no interactions, we would expect the strength of the association to be the same in each stratum. We also used durations of noise exposure of $<20$ years as a reference to calculate the OR for hearing loss. Statistical calculations were performed using SAS V.9.2 software (SAS Institute Inc., Cary, North Carolina, USA). For all of the analyses, a two-tailed $\mathrm{p}$ value $<0.05$ was considered statistically significant. The study protocol was approved by the Ethics Committee of the Buddhist Tzu Chi General Hospital (IRB098-50), and all of the participants provided written informed consent.

\section{RESULTS}

\section{Noise measurement}

The mean $8 \mathrm{~h}$ time-weighted average noise measurement in the 40 representative stone-processing workplaces was $87.7 \mathrm{dBA}$ (SD 9.9). There were no statistically significant differences in sound pressure levels between the different types of jobs (ANOVA test, F-ratio=0.46, $\mathrm{p}$ value $=0.83) \quad($ see online supplementary table $\mathrm{S} 1)$.

\section{VOCs detected in the stone-processing industry}

A total of 67 air samples were collected from 40 stoneprocessing workplaces, and 78 VOCs were identified. On the basis of percentages of measurements above the LOD, the most frequently detected VOCs were (in order of their detection frequency): 1,3-difluorobenzene (66/67), 1-bromo-2-fluorobenzene (66/67), p-bromofluorobenzene (66/67), 1-bromo3-fluorobenzene (66/67), chlorobenzene-d5 (64/67), bromochloromethane $(53 / 67)$, toluene $(48 / 67)$, acetone $(39 / 67)$, octamethylcyclotetrasiloxane $(26 / 67)$, hexamethylcyclotrisiloxane (23/67) and hexane (23/ $67)$. The 10 VOCs with the highest concentrations were trimethylsilanol, 3-methylpentane, butane, bromochloromethane, 1,3-difluorobenzene, ethyl acetate, p-bromofluorobenzene, 1-bromo-3-fluorobenzene, 1bromo-2-fluorobenzene and hexamethylcyclotrisiloxane (see online supplementary table S2).

\section{Use of personal protective equipment}

Regarding protective gear, $71 \%$ of the participants typically (more than once per week) used fans for ventilation, $30 \%$ typically used gauze masks, $5 \%$ typically used N95 masks, $6 \%$ typically used carbon-coated masks, and $3 \%$ typically used respirators for organic solvents. The majority of the participants $(85 \%)$ never used earplugs or earmuffs at work, and only $6 \%$ used them occasionally (table 1$)$.

\section{Characteristics of the study participants}

A total of 344 workers received health examinations. We excluded one participant with greater than 10 years of mining experience, six participants with more than 10 years of sandblasting experience, one participant who had worked in a pulp factory for more than 10 years, 14 participants with a history of otitis media, five with a history of ear trauma, and one participant with a history of congenital hearing loss. A total of 316 workers from 310 stone-processing workplaces were included in the final analysis, the majority of whom $(94 \%)$ were selfemployed. Their mean age was 51.3 years (SD 8.5), and $41 \%$ of the participants were male. Their average duration of work in the stone industry was 18.5 (SD 11.9) years, with $45.3 \%$ having worked for more than 20 years.

\section{Hearing examination}

The prevalence of noise-induced hearing loss was $31.7 \%$. Participants exposed to epoxy adhesives had significantly increased risks of having noise-induced hearing loss $(\mathrm{OR}=3.44,95 \%$ CI 2.01 to 5.89). After adjusting for age, exposure to epoxy adhesives significantly increased the risk of hearing loss at frequencies of 2, 3, 4 and $6 \mathrm{kHz}$ (table 2). When we stratified participants into three doses of exposure (noise plus epoxy adhesives, noise only and administrative staff), the hearing loss was more severe in stone workers with noise and epoxy adhesive exposure, followed by stone workers not exposed to epoxy adhesives and then by administrative staff who were exposed to neither noise nor epoxy adhesives (figure 1). The prevalence of noise-induced hearing loss was highest in the epoxy adhesive plus noise group (42\%), followed by the noise only group (21\%), and then the administrative staff group $(9.3 \%)$. Significant dose-response relationships for hearing loss were observed at 2, 3, 4 and $6 \mathrm{kHz}$ after adjusting for age (table 3 ).

\section{Synergistic effect of epoxy resin}

When stratified by epoxy adhesive exposure, the heterogeneity of the effects on hearing loss across strata showed a significant interaction between epoxy adhesives and noise at frequencies of 3,4 , and $6 \mathrm{kHz}$ (table 4 ).

\section{DISCUSSION}

Organic solvent exposure has been shown to cause hearing impairment in animal and human studies. Less is known about the risk of hearing loss due to the use of

\begin{tabular}{|c|c|c|}
\hline \multirow{2}{*}{$\begin{array}{l}\text { Frequency } \\
(\mathbf{k H z})\end{array}$} & \multicolumn{2}{|l|}{ Hearing loss $>25 \mathrm{~dB}$} \\
\hline & Crude OR & Age-adjusted OR \\
\hline 0.5 & $1.50(0.68$ to 3.31$)$ & $1.50(0.67$ to 3.36$)$ \\
\hline 1 & 1.78 (0.93 to 3.42$)$ & 1.85 (0.94 to 3.64$)$ \\
\hline 2 & $2.21^{*}(1.20$ to 4.06$)$ & $2.30^{*}(1.23$ to 4.31$)$ \\
\hline 3 & $2.42^{*}(1.47$ to 3.98$)$ & $2.59^{*}(1.54$ to 4.36$)$ \\
\hline 4 & $2.36^{*}(1.48$ to 3.75$)$ & $2.52^{*}(1.55$ to 4.10$)$ \\
\hline 6 & $2.24^{*}(1.42$ to 3.54$)$ & $2.49^{*}(1.52$ to 4.07$)$ \\
\hline 8 & 1.52 (0.97 to 2.39$)$ & 1.60 (0.98 to 2.62$)$ \\
\hline
\end{tabular}




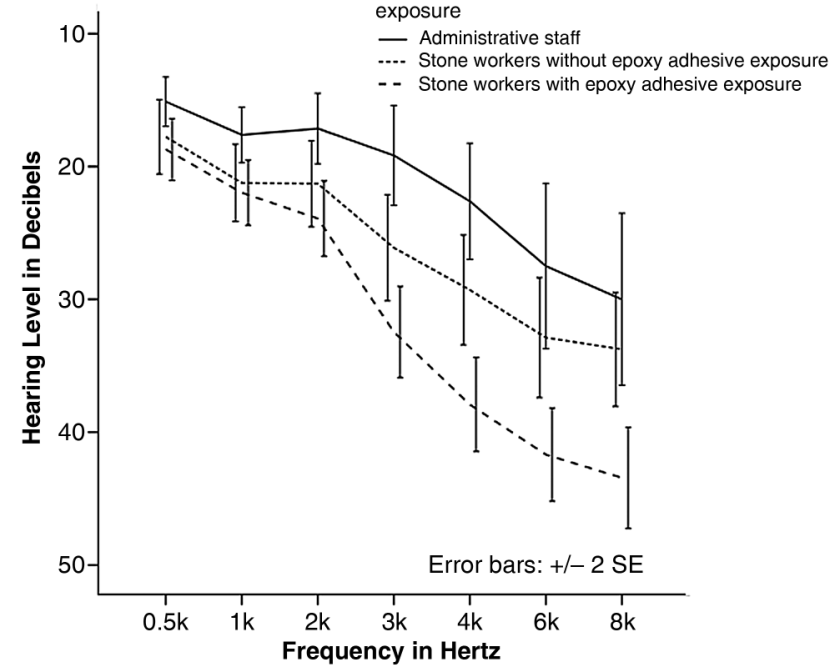

Figure 1 Hearing levels in the right ear, stratified by type of exposure. When the participants were stratified into the three exposure groups, the hearing losses were highest at all of the tested frequencies among stone workers with epoxy adhesive exposure, followed by stone workers without epoxy adhesive exposure and administrative staff.

epoxy resins containing mixed solvents. To the best of our knowledge, this is the first epidemiological study to show the synergistic interaction between noise and epoxy adhesives on hearing impairment.

\section{Strengths and limitations}

This study obtained detailed personal exposure history. Since there were no previous data, we conducted walkthrough surveys for each type of stone industry and discussed the hazardous exposures in stone workplaces with experienced workers. Exposure information was reconstructed using a questionnaire that was validated by experienced stone workers and industrial hygienists. The questionnaire allowed us to estimate exposures more precisely than would have been possible through employment records. To prevent recall biases, we required participants to provide labour insurance records, which were assessed against self-reported occupational history. To prevent recall biases, exposure history was obtained prior to the health examinations, and workers did not know the degrees of their hearing impairments when they completed the questionnaires. Smoking is a risk factor for hearing impairment among workers exposed to noise. ${ }^{16}$ In this study, there was no significant difference in the prevalence of smoking among workers with noise plus epoxy adhesive exposure, workers with noise exposure only, and administrative staff ( $p$ value $=0.45$ ). The study was based on a basic occupational health service programme for stone workers in Hualien. We performed consecutive walk-through surveys of stoneprocessing workplaces of Hualien between 2006 and 2015. The noise exposure measurements were taken between 2006 and 2009, and the air sampling was performed in 2014. Most stone industries are small businesses where workers use basic equipment, and there have been no important changes in processing methods during this time period. We thus tentatively believe that measurements taken in different years would not have influenced the results of the exposure assessment. Instead of using traditional sampling methods for specific VOCs in air, this study used the TO-15 analytic method to detect all trace VOCs. The sampling times were randomly selected and included times when workers were not performing specific procedures. The mean concentrations of individual VOCs were therefore reduced compared with the permissible exposure levels that were established on the basis of a time-weighted average exposure over a nominal 8 hours. The synergistic effect on auditory damage was consistent with previous studies in workers who were exposed to low levels of mixed organic solvents. ${ }^{17-19}$ However, the participants of this study were volunteers who might have various hearing-related concerns. Since the prevalence of noiseinduced hearing loss might increase, the external generalisation of these findings should be done carefully.

\section{Affected frequencies}

Studies have shown that exposure to mixed VOCs may affect hearing thresholds, especially in the middle and high frequencies. In this study, middle and high frequency hearing thresholds were significantly increased in the stone workers exposed to epoxy adhesives. A study of

Table 3 Age-adjusted ORs $(95 \% \mathrm{Cl})$ for hearing losses greater than $25 \mathrm{~dB}$ at each frequency in the right ear, stratified into three exposure groups and tested for trends

\begin{tabular}{|c|c|c|c|c|c|c|c|}
\hline Exposure & $0.5 \mathrm{kHz}$ & $1 \mathrm{kHz}$ & 2 kHz & $3 \mathbf{k H z}$ & 4 kHz & $6 \mathrm{kHz}$ & $8 \mathrm{kHz}$ \\
\hline $\begin{array}{l}\text { Noise and } \\
\text { epoxy adhesives } \\
(n=182)\end{array}$ & $\begin{array}{l}3.87 \\
(0.50 \text { to } 30.23)\end{array}$ & $\begin{array}{l}2.25 \\
(0.63 \text { to } 8.04)\end{array}$ & $\begin{array}{l}1.89 \\
(0.68 \text { to } 5.28)\end{array}$ & $\begin{array}{l}2.29^{*} \\
(1.00 \text { to } 5.23)\end{array}$ & $\begin{array}{l}2.82^{\star} \\
(1.29 \text { to } 6.13)\end{array}$ & $\begin{array}{l}2.17^{*} \\
(1.03 \text { to } 4.56)\end{array}$ & $\begin{array}{l}1.17 \\
(0.56 \text { to } 2.45)\end{array}$ \\
\hline $\begin{array}{l}\text { Noise only } \\
(n=89)\end{array}$ & $\begin{array}{l}3.38 \\
(0.41 \text { to } 28.17)\end{array}$ & $\begin{array}{l}1.35 \\
(0.34 \text { to } 5.29)\end{array}$ & $\begin{array}{l}0.79 \\
(0.25 \text { to } 2.50)\end{array}$ & $\begin{array}{l}1.24 \\
(0.52 \text { to } 2.99)\end{array}$ & $\begin{array}{l}1.19 \\
(0.51 \text { to } 2.79)\end{array}$ & $\begin{array}{l}0.83 \\
(0.37 \text { to } 1.89)\end{array}$ & $\begin{array}{l}0.64 \\
(0.28 \text { to } 1.45)\end{array}$ \\
\hline $\begin{array}{l}\text { Administrative } \\
\text { staff }(n=43)\end{array}$ & 1.0 & 1.0 & 1.0 & 1.0 & 1.0 & 1.0 & 1.0 \\
\hline$p$ for trend & 0.16 & 0.06 & 0.02 & $<0.05$ & $<0.05$ & $<0.05$ & 0.07 \\
\hline
\end{tabular}


Table 4 ORs $(95 \% \mathrm{Cl})$ for hearing losses greater than $25 \mathrm{~dB}$ at each frequency in the right ear

\begin{tabular}{|c|c|c|c|}
\hline & $\begin{array}{l}\text { Epoxy } \\
\text { adhesive } \\
\text { exposure }\end{array}$ & $\begin{array}{l}\text { Noise } \\
\text { exposure } \\
\geq 20 \text { years }\end{array}$ & OR $(95 \% \mathrm{Cl})$ \\
\hline \multirow[t]{4}{*}{$\mathrm{HL}_{0.5 \mathrm{kHz}}$} & No & No & 1.0 \\
\hline & & Yes & $0.64(0.13$ to 3.17$)$ \\
\hline & Yes & No & 1.0 \\
\hline & & Yes & $1.75(0.60$ to 5.05$)$ \\
\hline \multirow[t]{4}{*}{$\mathrm{HL}_{1 \mathrm{kHz}}$} & No & No & 1.0 \\
\hline & & Yes & 0.95 (0.28 to 3.22$)$ \\
\hline & Yes & No & 1.0 \\
\hline & & Yes & $2.46^{*}(1.01$ to 6.01$)$ \\
\hline \multirow[t]{4}{*}{$\mathrm{HL}_{2 \mathrm{kHz}}$} & No & No & 1.0 \\
\hline & & Yes & $1.12(0.36$ to 3.43$)$ \\
\hline & Yes & No & 1.0 \\
\hline & & Yes & $1.99(0.93$ to 4.25$)$ \\
\hline \multirow[t]{4}{*}{$\mathrm{HL}_{3 \mathrm{kHz}}$} & No & No & 1.0 \\
\hline & & Yes & 1.65 (0.70 to 3.91$)$ \\
\hline & Yes & No & 1.0 \\
\hline & & Yes & $2.18^{*}(1.15$ to 4.12$)$ \\
\hline \multirow[t]{4}{*}{$\mathrm{HL}_{4 \mathrm{kHz}}$} & No & No & 1.0 \\
\hline & & Yes & 1.91 (0.87 to 4.22$)$ \\
\hline & Yes & No & 1.0 \\
\hline & & Yes & $2.20^{*}(1.19$ to 4.08$)$ \\
\hline \multirow[t]{4}{*}{$\mathrm{HL}_{6 \mathrm{kHz}}$} & No & No & 1.0 \\
\hline & & Yes & $1.10(0.51$ to 2.38$)$ \\
\hline & Yes & No & 1.0 \\
\hline & & Yes & $2.35^{\star}$ (1.26 to 4.39$)$ \\
\hline \multirow[t]{4}{*}{$\mathrm{HL}_{8 \mathrm{kHz}}$} & No & No & 1.0 \\
\hline & & Yes & 1.68 (0.77 to 3.66$)$ \\
\hline & Yes & No & 1.0 \\
\hline & & Yes & 1.85 (0.99 to 3.43$)$ \\
\hline
\end{tabular}

petroleum refinery workers indicated that exposure to noise and a solvent mixture was associated with an elevated prevalence of high-frequency hearing loss. ${ }^{20}$ Morata et $a l^{17}$ found that workers from fibreglass and metal products manufacturing plants who were exposed to noise and styrene had significantly worse pure-tone thresholds at 2, 3, 4, and $6 \mathrm{kHz}$ compared with workers exposed to noise only or workers exposed to neither. Rabinowitz $e t a l^{21}$ examined the relationship between solvent exposure and hearing loss in aluminium industry workers and found that occupational exposure to organic solvent mixtures is a risk factor for high-frequency hearing loss. Sliwinska-Kowalska $e t a l^{1822} 23$ demonstrated that the synergistic effect of exposure to mixed organic solvents and noise affected hearing at middle and high frequencies in human and animal studies.

\section{Mechanisms}

It has been suggested that the damage induced by organic solvents is caused by a combination of ototoxicity and neurotoxicity. Animal studies have demonstrated that the inhalation of organic solvents results in hearing impairment and outer hair cell loss in the middle- frequency region in rats. ${ }^{24-26}$ Campo $e t a l^{27}$ also found that the inhalation of high concentrations of toluene (from 1000 to $2000 \mathrm{ppm}$ ) can cause severe loss of the outer hair cells in the organ of Corti in rats. Gagnaire et al administered 21 aromatic solvents orally by gastric intubation to Sprague-Dawley rats for 5 days/week for a 2-week period, and the results suggested that the structures of the side chains on aromatic rings may influence their ototoxicity ${ }^{28}$ A study of rats exposed to organic solvents revealed higher concentrations of solvents in the pons and cerebellum, which have higher lipid contents, suggesting that the neurotoxic properties of solvents are potentially related to their liposolubility. ${ }^{28}$ Decreased sensitivity of the middle ear acoustic reflex was observed in rats injected with toluene. ${ }^{29}$ Neurotoxic effects in the retrocochlear and central auditory pathways were also observed in workers exposed to organic solvents. ${ }^{30}$

\section{Combined hazardous effects}

Given that the ambient air at workplaces is not composed of a single VOC but rather a complex mixture with potential interactions between each VOC, we cannot attribute health effects to a particular VOC. In this study, we examined the combinations of chemicals in epoxy adhesive resin systems to estimate their health effects. The adverse reactions caused by epoxy adhesives may be due to the base epoxy resin, curing agents, diluents or other modifiers. In epoxy resin systems, organic solvent diluents are the most volatile of the materials, and they exhibit the highest lipophilic activity, ${ }^{1}$ which is associated with susceptibility to hearing damage. The ototoxicity of VOCs is typically more difficult to prove in epidemiological studies compared with animal studies because the concentrations of chemicals in workplaces are much lower than those used in animal studies. In addition, workers are typically exposed to a mixture of solvents with widely varying compositions and concentrations. ${ }^{31}$ A recent review by the International Commission on Biological Effects of Noise (ICBEN) Team concluded that the existing studies are not sufficient to reach a consensus on the health effects of mixed chemicals exposures on noise-induced hearing impairment. ${ }^{32}$ This epidemiological study is valuable because it could be used to assess the real health effects experienced by workers exposed to mixed chemicals. Our results also indicate that the roles of individual chemicals are not entirely clear and that further epidemiological studies of auditory damage are needed.

\section{Policy implication}

Currently, occupational legislation does not consider environmental chemicals hazardous to hearing. ${ }^{33}$ Although organic solvents have been widely used in industry, workers and occupational hygienists usually lack awareness of the ototoxic effects of VOCs. We recommend that suppliers of epoxy adhesives must include information related to possible hearing damage in the material safety data sheets provided to workers. 


\section{CONCLUSIONS}

Epoxy adhesives exacerbate hearing impairment in noisy environments, with the main impacts occurring in the middle and high frequencies. Given the wide use of organic solvents in industry, hearing conservation programmes must include the use of personal protective gear or ventilation equipment for solvents among workers with similar levels of exposure.

\section{Author affiliations}

${ }^{1}$ Department of Public Health and Institute of Occupational Medicine and Industrial Hygiene, National Taiwan University College of Public Health, Taipei, Taiwan

${ }^{2}$ Department of Environmental and Occupational Medicine, National Taiwan University Hospital, Taipei, Taiwan

${ }^{3}$ Green Energy \& Environmental Research Laboratories, Industrial Technology Research Institute, Hsinchu, Taiwan

${ }^{4}$ Department of Environmental and Occupational Medicine, National Taiwan University College of Medicine, Taipei, Taiwan

Acknowledgements The authors gratefully acknowledge Taiwan's Health Promotion Administration and the Ministry of Health and Welfare for providing the mortality certificate data.

Contributors $\mathrm{H}-\mathrm{YY}$ contributed to the study design, implementation and data analysis. R-HS contributed to the walk-through surveys and air sampling. $\mathrm{P}-\mathrm{CC}$ contributed to the quality assurance and control.

Funding This work was supported by a grant from the National Science Council (grant number 100-2314-B-320-002-MY3), the Ministry of Science and Technology (grant number MOST 104-2314-B-002-222), and the Department of Labor Safety and Health, Ministry of Labor (grant number 05-10201025).

Competing interests None declared.

Patient consent Obtained.

Ethics approval The Buddhist Tzu Chi General Hospital Institutional Review Board (IRB098-50).

Provenance and peer review Not commissioned; externally peer reviewed.

Data sharing statement No additional data are available.

Open Access This is an Open Access article distributed in accordance with the Creative Commons Attribution Non Commercial (CC BY-NC 4.0) license, which permits others to distribute, remix, adapt, build upon this work noncommercially, and license their derivative works on different terms, provided the original work is properly cited and the use is non-commercial. See: http:// creativecommons.org/licenses/by-nc/4.0/

\section{REFERENCES}

1. Health and Safety Executive. An assessment of skin sensitisation by the use of epoxy resin in the construction industry. HSE Books, 2003. http://www.hse.gov.uk/research/rrpdf/rr079.pdf (assessed 21 Dec 2015).

2. Gardiner TH, Waechter JM Jr, Wiedow MA, et al. Glycidyloxy compounds used in epoxy resin systems: a toxicology review. Regul Toxicol Pharmacol 1992;15:S1-77.

3. Department of Health Services, CA. Hazard Evaluation System and Information Service: epoxy resin systems. 1989. http://www. cdph.ca.gov/programs/hesis/Documents/epoxy.pdf (assessed 21 Dec 2015).

4. Bardana EJ Jr, Andrach $\mathrm{RH}$. Occupational asthma secondary to low molecular weight agents used in the plastic and resin industries. Eur $J$ Respir Dis 1983;64:241-51.

5. Meadway J. Asthma and atopy in workers with an epoxy adhesive. Br J Dis Chest 1980;74:149-54.

6. Rempel D, Jones J, Atterbury M, et al. Respiratory effects of exposure of shipyard workers to epoxy paints. Br J Ind Med 1991;48:783-7.
7. Bangsgaard N, Thyssen JP, Menné T, et al. Contact allergy to epoxy resin: risk occupations and consequences. Contact Derm 2012;67:73-7.

8. Angelini G, Rigano L, Foti C, et al. Occupational sensitization to epoxy resin and reactive diluents in marble workers. Contact Derm 1996;35:11-16.

9. Leow $\mathrm{YH}, \mathrm{Ng} \mathrm{SK}$, Wong WK, et al. Allergic contact dermatitis from epoxy resin in Singapore. Contact Derm 1995;33:355-6.

10. Johnson AC, Morata TC. 142. Occupational exposure to chemicals and hearing impairment. The Nordic Expert Group for Criteria Documentation of Health Risks from Chemicals. Nordic Expert Group. Gothenburg. Arbete och Hälsa 2010;44:177p.

11. Ahlman K, Backman AL, Partanen T. A health survey of granite workers in Finland: radiographic findings, respiratory function, hearing, electric sensory thresholds of the fingers and subjective symptoms. Scand J Work Environ Health 1975;1:109-16.

12. Yang HY. The initial efforts of BOHS in east Taiwan. International Conference of Occupational Health Services; Taipei, 2009.

13. Yang HY, Shie RH, Chen PC. Pulmonary fibrosis in workers exposed to non-asbestiform tremolite asbestos minerals. Epidemiology 2013;24:143-9.

14. Bisesi MS. Industrial hygiene evaluation methods. 2nd edn Washington DC: Lewis Publishers (CRC Press), 2003.

15. Finkelstein MM, Verma DK. Exposure estimation in the presence of nondetectable values: another look. AIHAJ 2001;62:195-8.

16. Starck J, Toppila E, Pyykko I. Smoking as a risk factor in sensory neural hearing loss among workers exposed to occupational noise. Acta Otolaryngol 1999;119:302-5.

17. Morata TC, Johnson AC, Nylen $\mathrm{P}$, et al. Audiometric findings in workers exposed to low levels of styrene and noise. J Occup Environ Med 2002;44:806-14.

18. Sliwinska-Kowalska M, Zamyslowska-Szmytke E, Szymczak W, et al. Ototoxic effects of occupational exposure to styrene and co-exposure to styrene and noise. J Occup Environ Med 2003;45:15-24.

19. Kim J, Park H, Ha E, et al. Combined effects of noise and mixed solvents exposure on the hearing function among workers in the aviation industry. Ind Health 2005;43:567-73.

20. Morata TC, Fiorini AC, Fischer FM, et al. Toluene-induced hearing loss among rotogravure printing workers. Scand J Work Environ Health 1997;23:289-98

21. Rabinowitz PM, Galusha D, Slade MD, et al. Organic solvent exposure and hearing loss in a cohort of aluminium workers. Occup Environ Med 2008;65:230-5.

22. Sliwinska-Kowalska M, Zamyslowska-Szmytke E, Szymczak W, et al. Hearing loss among workers exposed to moderate concentrations of solvents. Scand J Work Environ Health 2001;27:335-42.

23. Sliwinska-Kowalska M, Zamyslowska-Szmytke E, Szymczak W, et al. Effects of coexposure to noise and mixture of organic solvents on hearing in dockyard workers. J Occup Environ Med 2004;46:30-8.

24. Cappaert NL, Klis SF, Baretta AB, et al. Ethyl benzene-induced ototoxicity in rats: a dose-dependent mid-frequency hearing loss. $J$ Assoc Res Otolaryngol 2000;1:292-9.

25. Cappaert NL, Klis SF, Muijser H, et al. Simultaneous exposure to ethyl benzene and noise: synergistic effects on outer hair cells. Hear Res 2001;162:67-79.

26. Loquet G, Campo P, Lataye R. Comparison of toluene-induced and styrene-induced hearing losses. Neurotoxicol Teratol 1999;21:689-97.

27. Campo $\mathrm{P}$, Lataye $\mathrm{R}$, Cossec $\mathrm{B}$, et al. Toluene-induced hearing loss: a mid-frequency location of the cochlear lesions. Neurotoxicol Teratol 1997;19:129-40.

28. Campo P, Loquet G, Blachere $\mathrm{V}$, et al. Toluene and styrene intoxication route in the rat cochlea. Neurotoxicol Teratol 1999;21:427-34.

29. Rumeau C, Campo P, Venet $T$, et al. Toluene effect on the olivocochlear reflex. Toxicol Sci 2011:121:140-5.

30. Gopal KV. Audiological findings in individuals exposed to organic solvents: case studies. Noise Health 2008:10:74-82.

31. Hoet P, Lison D. Ototoxicity of toluene and styrene: state of current knowledge. Crit Rev Toxicol 2008;38:127-70.

32. Leroux T, Klaeboe R. Combined exposures: an update from the International Commission on Biological Effects of Noise. Noise Health 2012;14:313-14.

33. Prasher D, Morata T, Campo P, et al. NoiseChem: an European Commission research project on the effects of exposure to noise and industrial chemicals on hearing and balance. Noise Health 2002;4:41-8. 